\title{
Overcoming dormancy in Bauhinia scandens seeds
}

\section{Superação de dormência de sementes de Bauhinia scandens}

\author{
Tatiane Sanches Jeromini ${ }^{1 *}$; Thaís Soares Pereira ${ }^{2}$; Cibele Chalita Martins ${ }^{3}$; \\ Givanildo Zildo da Silva ${ }^{4}$
}

Highlights:

The most probable cause of dormancy for seeds of $B$. scandens is the impermeability of the integument. $B$. scandens seeds do not demonstrate synchrony in the germination process.

$B$. scandens seeds should be chemically scarified with $\mathrm{H}_{2} \mathrm{SO}_{4}$ before sowing.

\begin{abstract}
Bauhinia scandens, an ornamental climbing vine, recently introduced in Brazil, in 2006 which has been gaining prominence due to its anti-tumor medicinal properties. A common feature amongst species of the Fabaceae family is dormancy due to the impermeability of the integument of the seed to water. The demand for seedlings of this species makes it necessary to elucidate the germination process and initial seedling growth. The objective of this study was to determine a method to overcome dormancy, thereby promoting seed germination and initial growth of $B$. scandens seedlings. The seeds were subjected to one of four treatments, besides the control: mechanical scarification, immersion in water $\left(26^{\circ} \mathrm{C}\right.$ for 24 hours), immersion in hot water $\left(86^{\circ} \mathrm{C}\right.$ for 24 hours, then $\left.26^{\circ} \mathrm{C}\right)$ and immersion in $\mathrm{H}_{2} \mathrm{SO}_{4}(95 \%)$ for $15,30,45$, and 60 minutes. The seeds were evaluated for water content, germination (normal, abnormal seedlings, dormant and dead seeds), first count, mean germination time and relative frequency of germination. The seedlings were evaluated for emergence in sand, first count, emergence speed index, length and dry matter mass. $B$. scandens seeds should be immersed in $\mathrm{H} 2 \mathrm{SO} 4$ for 45 and 60 minutes before sowing to overcome dormancy, in order to promote and standardize seed germination and enhance initial growth of the seedlings.
\end{abstract}

Key words: Antitumor properties. Bauhinia-climbing vine. Fabaceae. Relative frequency.

\section{Resumo}

Bauhinia scandens é uma trepadeira ornamental, recentemente trazida para o Brasil, que vem ganhando destaque devido às propriedades medicinais antitumorais. Uma característica comum entre as espécies da família Fabaceae é a dormência nas sementes por impermeabilidade do tegumento e para a demanda por mudas desta espécie torna necessário o conhecimento sobre o processo germinativo das sementes e o crescimento inicial das plântulas. O objetivo do trabalho foi determinar um método para a superação da dormência, promoção da germinação das sementes e crescimento inicial de plântulas de B. scandens. As sementes foram submetidas aos seguintes tratamentos: testemunha, escarificação mecânica, imersão

1 Discente de Doutorado, Universidade Estadual Paulista "Júlio de Mesquita Filho", Faculdade de Ciências Agrárias e Veterinárias, UNESP/FCAV, Jaboticabal, SP, Brasil. E-mail: tatiane_jeromini@hotmail.com

2 Discente de Mestrado, UESP/FCAV, Jaboticabal, SP, Brasil. E-mail: thaisoares_13@hotmail.com

3 Prof ${ }^{a}$ Livre-Docente, UNESP/FCAV, Jaboticabal, SP, Brasil. E-mail: cibele.chalita@unesp.br

4 Prof., Permanente do Programa de Pós-Graduação, Universidade Federal de Goiás, UFG, Regional de Jataí, Jataí, GO, Brasil. E-mail: givanildozildo@hotmail.com

* Author for correpondence 
em água $\left(26^{\circ} \mathrm{C} / 24 \mathrm{~h}\right)$, imersão em água quente $\left(86^{\circ} \mathrm{C}\right.$ e ao final do período de $\left.24 \mathrm{~h}, 26^{\circ} \mathrm{C}\right)$, imersão em $\mathrm{H}_{2} \mathrm{SO}_{4}(95 \%)$ por $15,30,45$ e 60 minutos. As sementes foram avaliadas quanto ao teor de água, germinação (plântulas normais, anormais, sementes dormentes e mortas), primeira contagem, tempo médio de germinação e frequência relativa. As plântulas foram avaliadas quanto à emergência em areia, primeira contagem, índice de velocidade de emergência, comprimento e massa de matéria seca. As sementes de $B$. scandens devem ser imersas $\mathrm{em}_{2} \mathrm{SO}_{4}$ por 45 e 60 minutos antes da semeadura para superar a dormência, promover e uniformizar a germinação de sementes e proporcionar maior crescimento inicial de plântulas.

Palavras-chave: Propriedade antitumoral. Bauhinia-trepadeira. Fabaceae. Frequência relativa.

\section{Introduction}

B. scandens L.- Fabaceae., an ornamental and relatively unknown climbing vine in Brazil, began to be commercialized in 2006 in São Paulo (Bacher, 2018). The plant has become more prominent due to the medical properties of the compound 1-O-alkyl glycerol, which is found in its leaves (Hazra \& Chatterjee, 2008). These authors established the antitumor property of this active principle through the Brine shrimp lethality assay, an internationally accepted bioassay.

Poonsri, Pluempanupat, Chitchirachan, Bullangpoti and Koul (2015) also identified the insecticidal properties in extracts from $B$. scandens leaves in the control of Plutella xytostella, one of the main pests found in brassicas, so B. scandens presents more than one phytochemical advantage to its cultivation.

Other plants of the same genus, such as $B$. monandra, $B$. forficata, $B$. purpurea, and $B$. platypetala, were also used to create various phototherapies (Melo, Nascimento, Amorim, Andrade Lima, \& Albuquerque, 2004). These plants possess anxiolytic and antibacterial properties and have therefore been indicated for the treatment of diabetes (Albuquerque, Simira, \& Silva, 2000; Ahmed et al., 2012; Santos et al., 2012; Pereira et al., 2014).

A common feature among species of the Fabaceae family is dormancy due to the impermeability of the integument to water, which may occur in up to $98 \%$ of the seeds (Martins, Machado, Martinelli-Seneme, \& Zucareli, 2012; Rolston, 1978; Cruz, Carvalho, \&
Oliveira, 1997). This phenomenon is a problem for farmers and nursery owners because it causes delays and a lack of uniformity in germination, thereby hindering the production of seedlings (Martins et al., 2012).

However, some treatments can be used on the seeds to solve this dormancy problem and promote germination. Immersing seeds of $B$. monandra in $\mathrm{H}_{2} \mathrm{SO}_{4}$ for 20 minutes and mechanically scarifying the integument of $B$. ungulata with sandpaper were effective in overcoming dormancy and promoting germination (M. C. S. Alves, Medeiros, Andrade, \& Teófilo, 2000).

For $B$. divaricata, the best results in promoting seedling emergence and vigor, and in overcoming seed dormancy were provided when a small cut was made in the region opposite the micropyle (A. U. Alves, Dornelas, Bruno, Andrade, \& Alves, 2004). For seeds of $B$. forficata, chemical scarification with sulfuric acid for 5 minutes and mechanical scarification with sandpaper were efficient (T. M. Oliveira et al., 2012a). Hence, the efficiency of the method used in overcoming dormancy depends on the species of Bauhinia seed treated (Martins \& Nakagawa, 2008).

The Rules for Seed Analysis - RAS Ministério da Agricultura, Pecuária e Abastecimento [MAPA] (2013) recommend that seeds with an impermeable integument at the end of the test be immersed in water for a period of 24 to 48 hours and then undergo mechanical scarification with sandpaper or chemical scarification with $95 \% \mathrm{H}_{2} \mathrm{SO}_{4}$. No reports were found in the literature on the dormancy or germinative behavior of B. scandens seeds. 
Because the species affects the efficiency of the method for overcoming dormancy in Bauhinia seeds, the present study sought to identify an efficient method for overcoming dormancy and promoting seed germination and initial growth in $B$. scandens seedlings.

\section{Material and Methods}

Fruits of $B$. scandens were harvested from 10 plants in Botucatu, São Paulo, and sent to the Laboratory of Seed Analysis of the Department of Plant Production of UNESP, Jaboticabal, São Paulo. The seeds were extracted from the pods and the inert materials (such as plant debris, soil, visibly deteriorated, broken and malformed seeds) were removed. The sample was homogenized, and a working sample of $300 \mathrm{~g}$ was separated, according to the recommendations contained in Mapa (2013). The seeds were stored in a cold chamber $\left(10{ }^{\circ} \mathrm{C}\right.$ and $60 \% \mathrm{RH}$ ) for 10 days until the treatment protocols commenced.

The study consisted of eight treatments: control - seeds without treatment; mechanical scarification manual rubbing of the seeds on sandpaper (number 150 ) in the region opposite the hilum; immersion of the seeds in hot water - with initial temperatures of $86{ }^{\circ} \mathrm{C}$ for 24 hours decreased to $26^{\circ} \mathrm{C}$; immersion in water for 24 hours - constant temperature of $26^{\circ} \mathrm{C}$; chemical scarification for 15, 30, 45 and 60 minutes - immersion of the seeds in sulfuric acid $\left(\mathrm{H}_{2} \mathrm{SO}_{4}\right) 36$ $\mathrm{N} 95 \%$, for the allotted time, followed by washing under running water. Except for the control and mechanical scarification treatments, treatments were followed by drying of the seeds in the shade for $24 \mathrm{~h}\left(25^{\circ} \mathrm{C}, 50 \% \mathrm{RH}\right)$.

In order to evaluate the physiological quality of the seeds, the following tests and determinations were performed:

Water content - After processing, two replicates of 10 seeds were used, using the kiln drying method at $105 \pm 3{ }^{\circ} \mathrm{C}$ for 24 hours (MAPA, 2009).
Germination - Following the recommendation of Mapa (2013) for other species of the same genus (Bauhinia), four replicates of 50 seeds were evaluated, arranged on paper towel moistened with distilled water in the amount of 2.5 times the dry paper mass, and maintained at $25^{\circ} \mathbf{C}$ for 27 days. At the end of the test, the counts of normal, abnormal seedlings, dormant (hard) and dead seeds were calculated and expressed as a percentage.

First germination count - This was estimated together with the germination test, this involved counting the normal seedlings on the 8th day after sowing. The results were expressed as a percentage.

Mean germination time - This was estimated in conjunction with the germination test and obtained by applying the formula by Labouriau (1983), where:

MGT $=\left(\sum\right.$ niti $) / \sum$ ni, where: $n_{i}=$ number of germinated seeds per day; $\mathrm{t}_{\mathrm{i}}=$ incubation time.

Relative germination frequency - This was performed in conjunction with the germination test and obtained by applying the formulas proposed by Labouriau and Valadares (1976) where:

$\mathrm{RF}=\mathrm{ni} / \sum$ ni, where: $\mathrm{n}_{\mathrm{i}}=$ number of germinated seeds per day; $\Sigma n_{i}=$ total number of germinated seeds.

Seedling emergence in sand-Four replicates of 50 seeds were sown at a depth of $0.5 \mathrm{~cm}$ in autoclaved sand moistened with water (at $60 \%$ of the retention capacity of the substrate in water (MAPA, 2009) and stored in transparent plastic boxes $(22 \times 15 \times 5 \mathrm{~cm})$. The test was conducted at $26 \pm 3^{\circ} \mathrm{C}$ for 27 days, after which the seedlings were counted. Seedlings with well-developed primary root and hypocotyl, and that had cotyledons above the substrate were considered to have emerged (Jeromini, Scalon, Pereira, Fachinelli, \& Scalon, 2015). The result was expressed as a percentage of seeds sown.

First emergence count - This was estimated in conjunction with the emergence test, involved counting the emerged seedlings on the 8th day 
after sowing, and the result was expressed as a percentage.

Emergence speed index - This was estimated in conjunction with the seedling emergence test, involved counting the emerged seedlings daily and applying the formula proposed by Maguire (1962).

Length of seedlings - This was estimated at the end of the emergence test, the distance between the root cap and the apex (region of cotyledon insertion) of 20 randomly selected seedlings was measured by a ruler in millimeters and expressed in centimeters per seedling.

Dry mass of seedlings - After measuring the length of the seedlings, the cotyledons were removed, and the remaining plant was packed in Kraft paper bags and kept in a greenhouse at 65 ${ }^{\circ} \mathrm{C}$ for 24 hours with forced air circulation. The seedlings were then weighed on a precision scale $(0.0001 \mathrm{~g})$ and the result was expressed in grams per seedling (Nakagawa, 1999).
The statistical design was a completely randomized design with eight treatments and four replications. The percentage of abnormal seedlings and dead seeds were transformed using $(x+0.5)^{1 / 2}$ and sine $\operatorname{arc}[(\mathrm{x} / 100)]^{1 / 2}$ transformations, respectively, in order to guarantee the normality of the residuals, and then evaluated by the Shapiro-Wilk test. The averages presented were from the original data. All data were submitted for analysis of variance by F-test, and Tukey's test was performed to compare the averages, at a $5 \%$ level of significance $(\mathrm{P}<0.05)$.

\section{Results and Discussion}

The seeds of $B$. scandens had an initial water content of $6 \%$ (b. u.), this value is similar to other species of the same genus used for conducting laboratory tests (Alves et al., 2004). Table 1 summarizes the effect of the treatments for overcoming dormancy for all the observed and calculated variables.

\section{Table 1}

Germination (G), dormant seeds (D), abnormal seedlings (A), dead seeds (M), first germination count (PC) and mean germination time (MGT) of Bauhinia scandens submitted to treatments for overcoming dormancy

\begin{tabular}{|c|c|c|c|c|c|c|}
\hline Treatments & $\mathrm{G}(\%)$ & $\mathrm{D}(\%)$ & $\mathrm{A}(\%)$ & $\mathrm{M}(\%)$ & $\mathrm{PC}(\%)$ & MGT (days) \\
\hline Control & $1 \mathrm{f}$ & $90 \mathrm{~d}$ & $0 \mathrm{a}$ & $9 \mathrm{a}$ & $0 \mathrm{c}$ & $15 \mathrm{~b}$ \\
\hline Mechanical scarification & $57 \mathrm{~b}$ & $8 \mathrm{a}$ & $10 \mathrm{bc}$ & $25 \mathrm{~b}$ & $30 \mathrm{a}$ & $11 \mathrm{a}$ \\
\hline Immersion in hot water & $12 \mathrm{e}$ & $58 \mathrm{c}$ & $5 \mathrm{abc}$ & $25 \mathrm{~b}$ & $5 \mathrm{bc}$ & $13 \mathrm{ab}$ \\
\hline Imersion in water & $1 \mathrm{f}$ & $88 \mathrm{~d}$ & $0 \mathrm{a}$ & $11 \mathrm{a}$ & $1 \mathrm{c}$ & $13 \mathrm{ab}$ \\
\hline $\mathrm{H}_{2} \mathrm{SO}_{4}$ for 15 & $29 d$ & $57 \mathrm{c}$ & $4 \mathrm{ab}$ & $10 \mathrm{a}$ & $12 \mathrm{~b}$ & $11 \mathrm{a}$ \\
\hline $\mathrm{H}_{2} \mathrm{SO}_{4}$ for 30 & $46 \mathrm{c}$ & $38 \mathrm{~b}$ & $6 \mathrm{abc}$ & $10 \mathrm{a}$ & $27 \mathrm{a}$ & $11 \mathrm{a}$ \\
\hline $\mathrm{H}_{2} \mathrm{SO}_{4}$ for 45 & $75 \mathrm{a}$ & $5 \mathrm{a}$ & $7 \mathrm{bc}$ & $12 \mathrm{a}$ & $32 \mathrm{a}$ & $13 \mathrm{ab}$ \\
\hline $\mathrm{H}_{2} \mathrm{SO}_{4}$ for 60 & $75 \mathrm{a}$ & $5 \mathrm{a}$ & $10 \mathrm{c}$ & $10 \mathrm{a}$ & $40 \mathrm{a}$ & $12 \mathrm{ab}$ \\
\hline Mean square & $3812,45^{* *}$ & $5045,24^{* *}$ & $61,95^{* *}$ & $185,88^{* *}$ & $856,56^{* *}$ & $7,17^{*}$ \\
\hline d.m.s. & 7,70 & 14,07 & 6,26 & 10,72 & 8,10 & 3,68 \\
\hline CV (\%) & 8,88 & 13,72 & 51,25 & 32,74 & 19,68 & 12,86 \\
\hline
\end{tabular}

** and * Significant at $1 \%$ and $5 \%$ probability, respectively, by the F-test. Averages followed by the same lowercase letter in the column do not differ from each other by the Tukey test at $5 \%$ probability.

It was verified that the $\mathrm{H}_{2} \mathrm{SO}_{4}$ scarification treatments at 45 and 60 minutes were superior to all other treatments, providing the highest percentage of germination at $75 \%$. The mechanical scarification 
was the second-best treatment, as it resulted in the germination of $57 \%$ of the seeds (Table 1). These treatments reduced the percentage of dormant seeds from $90 \%$ (control) to $8 \%, 5 \%$ and $5 \%$, respectively. These results, which favored overcoming dormancy and the promotion of germination due to scarification with $\mathrm{H}_{2} \mathrm{SO}_{4}$ and mechanical scarification with sandpaper, were similar to those reported for seeds of B. forficata, B. variegata (T. M. Oliveira et al., 2012a), B. divaricata (Lopes, Barbosa, \& Capucho, 2007), B. ungulata and B. monandra (Alves et al., 2000).

The other treatments that were evaluated (the immersion in hot or room temperature water and the immersion in $\mathrm{H}_{2} \mathrm{SO}_{4}$ for 15 and 30 minutes) were less effective $(\mathrm{P}>0.05)$ in overcoming dormancy and in promoting germination. In comparison to the control, only the immersion of the seeds in water at $26{ }^{\circ} \mathrm{C}$ and in $\mathrm{H}_{2} \mathrm{SO}_{4}$ for 15 minutes did not increase the percentage of abnormal seedlings. Mechanical scarification and the immersion of the seeds in hot water increased the percentage of dead seeds. Abnormal and dead seeds can be attributed to the damage caused to the seed embryos during mechanical scarification and immersion in hot water. Mechanical scarification depends greatly on the technician conducting the process, the force employed, and the amount of material removed from the seed, which could account for more damage to the embryo than treatment with $\mathrm{H}_{2} \mathrm{SO}_{4}$ (A. K. M. Oliveira et al, 2012b; Ataíde, Bicalho, Dias, Castro, \& Alvarenga, 2013).

In this study, the rupture of the integument by chemical and mechanical means significantly improved germination in B. scandens seeds, and hence, it is possible to conclude that impermeability of the integument is the dominant cause of seed dormancy. Rupture of the integument promoted germination consistent with seeds of other species of the Fabaceae family (Alves et al., 2000; Alves et al., 2004; Martins et al., 2012; A. K. M. Oliveira et al., 2012b).
Mechanical scarification and chemical scarification with $\mathrm{H}_{2} \mathrm{SO}_{4}$ for 30,45 , and 60 minutes provided the best results in terms of seed vigor, as measured by first count. Among these four treatments, only immersion in $\mathrm{H}_{2} \mathrm{SO}_{4}$ for 30 minutes was not efficient in overcoming dormancy and promoting germination.

Mechanical scarification and chemical scarification in $\mathrm{H}_{2} \mathrm{SO}_{4}$ for 15 and 30 minutes provided a faster average seed germination time than the control $(\mathrm{P}<0.05)$. Therefore, when considering the average germination time, none of the two best treatments for germination promotion were able to accelerate the germination speed compared to the control. Although the mean germination times were similar between the treatments, it was found that the treatments had different effects on the synchronization and distribution of germination over time (Figure 1).

Relative frequency peaks are related to the synchronization of germination, i.e., the higher the number of peaks, the wider the distribution of germination days (Santana \& Ranal, 2004). A unimodal relative frequency line (Figure 1A) was observed in the control treatment sample plot. This indicates a single germination peak at 15 days after sowing. The seeds of the control treatment showed a lower relative frequency of germination compared to the other treatments, which presented polymodal lines, i.e., several peaks of germination, and hence a greater spread in germination time (Figure 1B, C, D, E, F, G, H).

Faster germination (on the $6^{\text {th }}$ day) was observed for the seeds that were subjected to mechanical scarification and immersion in $\mathrm{H}_{2} \mathrm{SO}_{4}$ for 30,45 , and 60 minutes (Figure 1B, F, G and H), whereas germination for the other treatments was delayed and occurred from day 7 (Figure 1A, C, D and E). Mechanical and chemical scarification of seeds can therefore reduce germination time. 


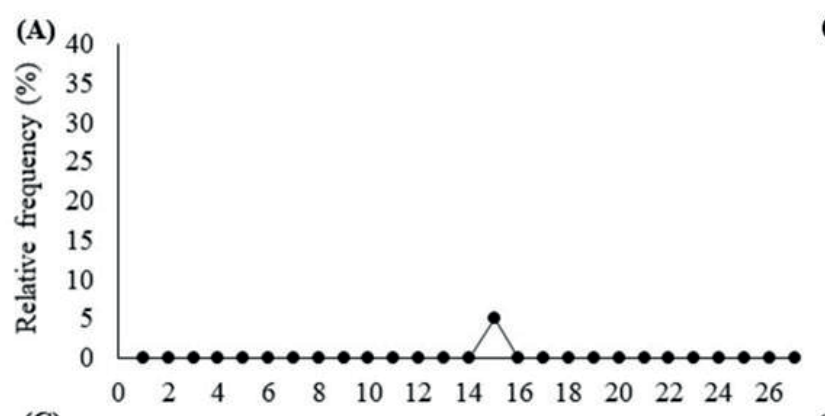

(C)
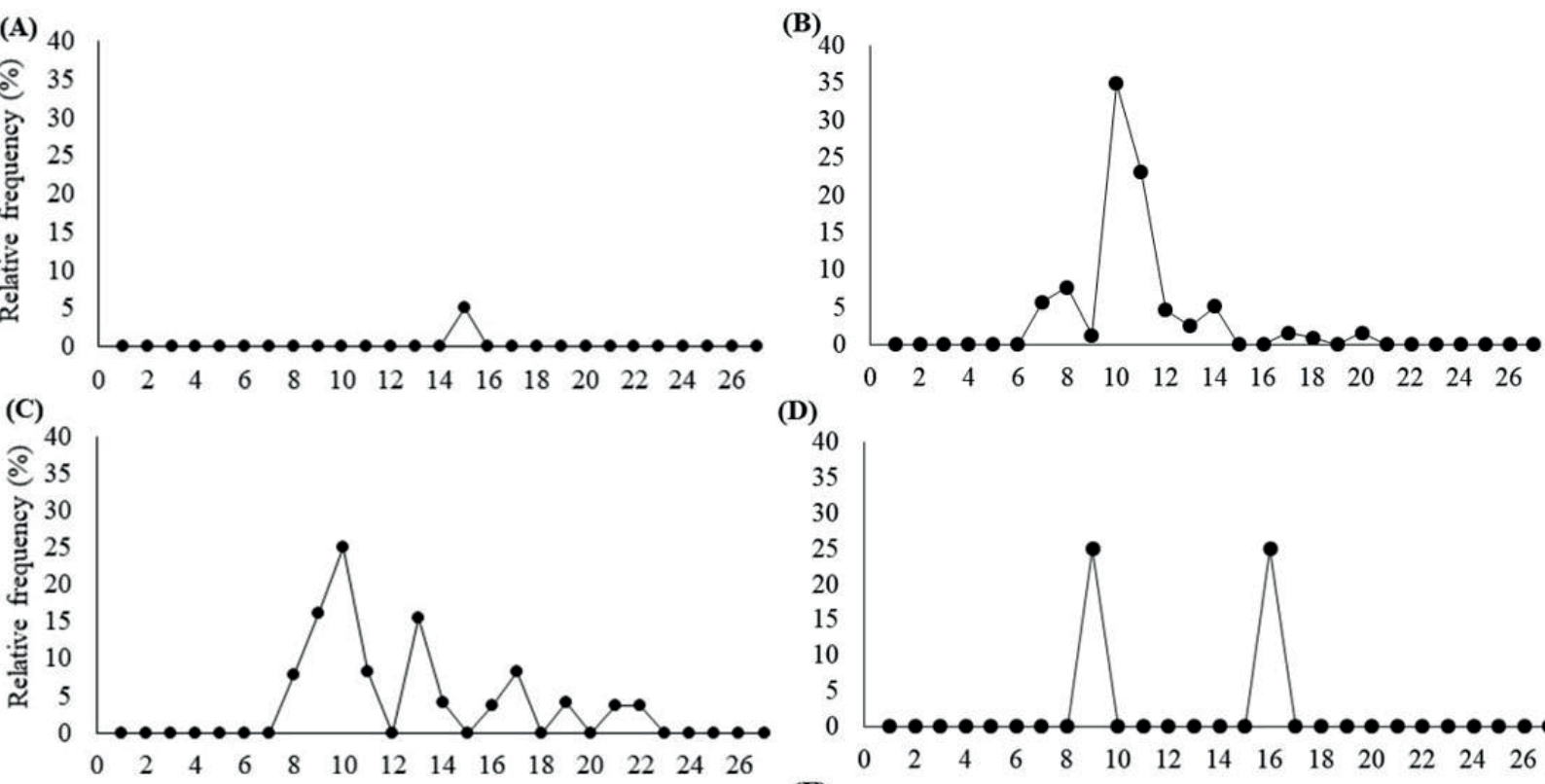

(D)
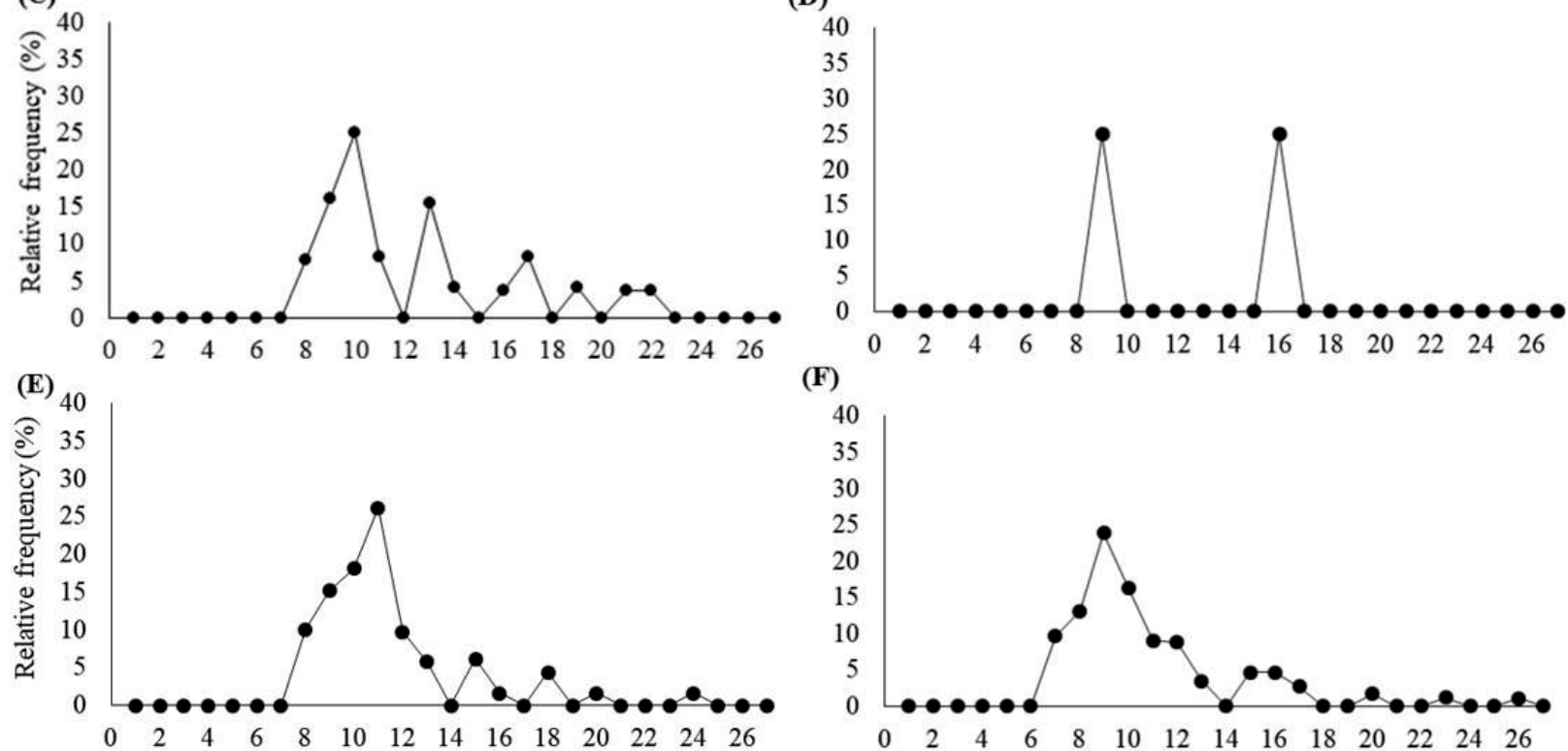

(F)

(G)
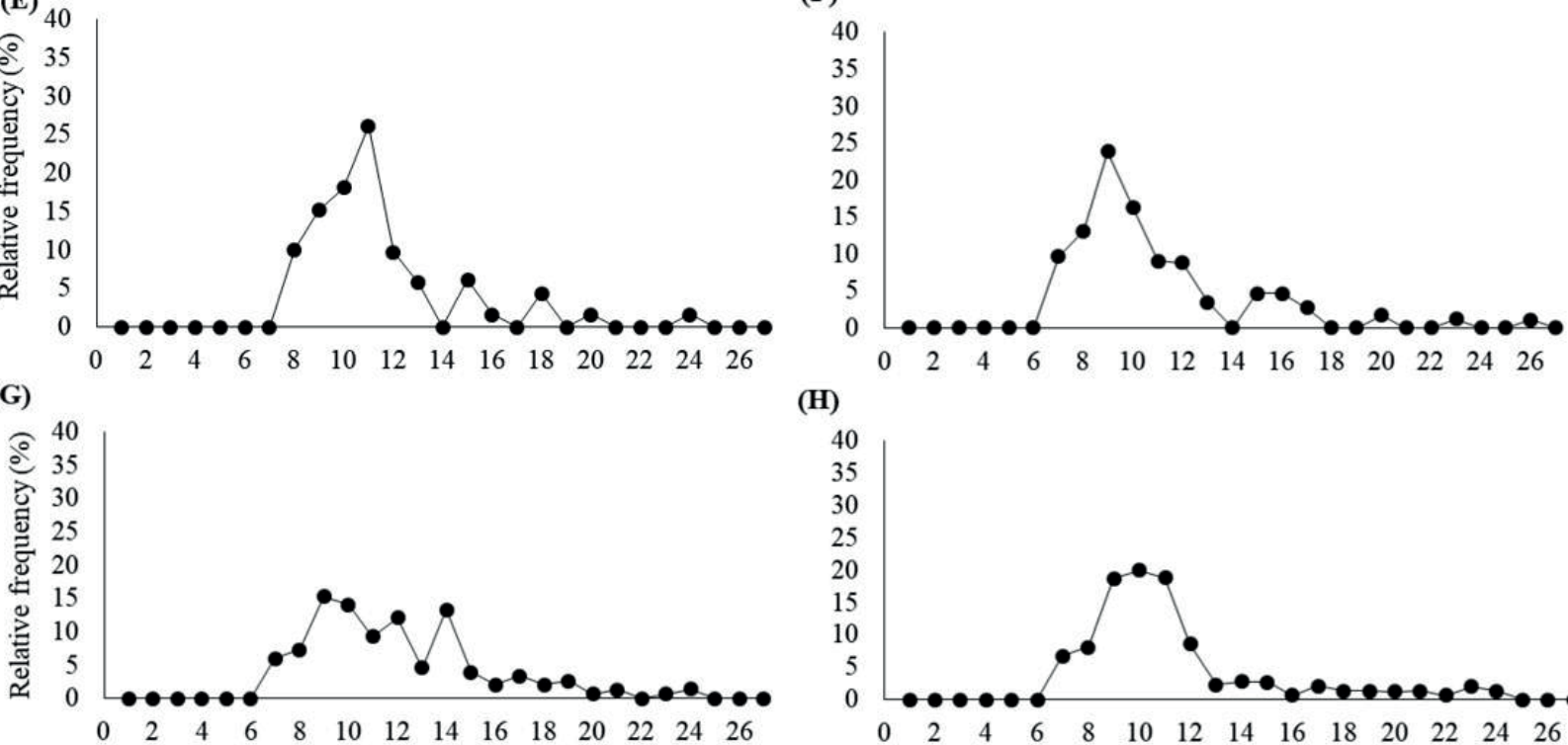

(H)

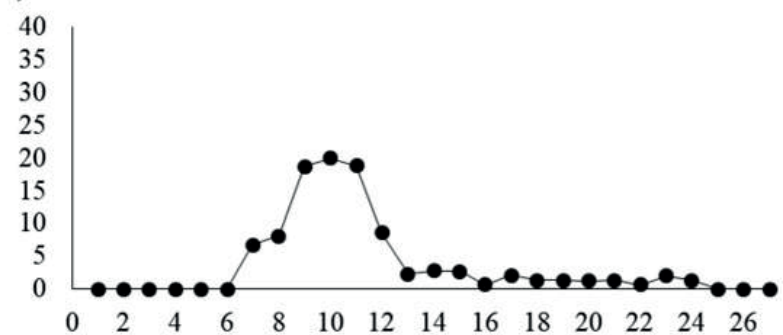

Figure 1. Relative frequency of germination of Bauhinia scandens seeds from the control treatment (A) and subjected to mechanical scarification (B), immersion in hot water (C), cold water (D), $\mathrm{H}_{2} \mathrm{SO}_{4}$ for 15 minutes (E), $\mathrm{H}_{2} \mathrm{SO} \mathrm{f}_{4}$ for 30 minutes (F), $\mathrm{H}_{2} \mathrm{SO}_{4}$ for 45 minutes $(\mathrm{G}), \mathrm{H}_{2} \mathrm{SO}_{4}$ for 60 minutes $(\mathrm{H})$.

Figure 1 demonstrates that treatments of $B$. scandens seeds to overcome dormancy do not promote synchrony in the germination process, as evidenced by the low relative frequency of germination. Seeds of native species that demonstrate dormancy often display this characteristic Ranal, Santana, Ferreira and Mendes-Rodrigues (2009).

Even though mechanical scarification and immersion in $\mathrm{H}_{2} \mathrm{SO}_{4}$ for 45 and 60 minutes were efficient in overcoming dormancy, they did not change the germination pattern of the seeds of this species. This effect was observed in seeds of Chamaecrista desvauxii (Gomes, Lopes, Silva, \& Matheus, 2012), Erythrina velutina (Alves et al., 2008), B. divaricata (Alves et al., 2004), and B. variegata (Lopes et al., 2007). 
For the variables related to the growth of the seedlings in sand, the treatments to overcome dormancy in the seeds only significantly affected the percentage of emergence, first emergence count and emergence speed index (Table 2). The best emergence of seedlings in sand was obtained by immersing the seeds in $\mathrm{H}_{2} \mathrm{SO}_{4}$ for 45 and 60 minutes and with mechanical scarification. These results were similar to those obtained for germination and dormancy (Table 1).

\section{Table 2}

Averages of emergence (E), first emergence count (PCE) and emergence speed index (ESI) of Bauhinia scandens seeds due to different methods of overcoming dormancy

\begin{tabular}{lccc}
\hline Treatments & E (\%) & PCE $(\%)$ & ESI \\
\hline Control & $1 \mathrm{~d}$ & $1 \mathrm{~d}$ & $0,07 \mathrm{e}$ \\
Mechanical scarification & $55 \mathrm{ab}$ & $53 \mathrm{~b}$ & $2,78 \mathrm{~b}$ \\
Immersion in hot water & $14 \mathrm{~d}$ & $9 \mathrm{~d}$ & $0,46 \mathrm{e}$ \\
$\mathrm{Imersion} \mathrm{in} \mathrm{water}_{\mathrm{H}_{2} \mathrm{SO}_{4} \text { for } 15,}$ & $1 \mathrm{~d}$ & $0 \mathrm{~d}$ & $0,08 \mathrm{e}$ \\
$\mathrm{H}_{2} \mathrm{SO}_{4}$ for 30 & $28 \mathrm{c}$ & $24 \mathrm{c}$ & $1,08 \mathrm{~d}$ \\
$\mathrm{H}_{2} \mathrm{SO}_{4}$ for $45^{\prime}$ & $45 \mathrm{~b}$ & $34 \mathrm{c}$ & $2,20 \mathrm{c}$ \\
$\mathrm{H}_{2} \mathrm{SO}_{4}$ for 60 & $64 \mathrm{a}$ & $61 \mathrm{ab}$ & $3,28 \mathrm{a}$ \\
\hline $\mathrm{Mean}$ square & $69 \mathrm{a}$ & $66 \mathrm{a}$ & $3,47 \mathrm{a}$ \\
d.m.s. & $3042,78^{* *}$ & $2871,14^{* *}$ & $8,13^{* *}$ \\
CV $(\%)$ & 13,85 & 11,10 & 0,45 \\
\hline
\end{tabular}

** Significant at $1 \%$ probability by F-test. Averages followed by the same lowercase letter in the column do not differ by Tukey test at $5 \%$ probability.

Despite the efficiency of the sulfuric acid treatment, there are disadvantages to its use, such as the danger of burns to the technician who performs the scarification of seeds. The corrosive action of the acid, the rise in temperature, the splashing and the high cost of the acid preclude the use of large volumes of $\mathrm{H}_{2} \mathrm{SO}_{4}$ (P.A.) for the treatment of seeds. Therefore, in seedling nurseries, mechanical scarification with sandpaper to overcome dormancy is most often employed (Martins \& Nakagawa, 2008; Martins et al., 2012).

Seed vigor of $B$. scandens, as evidenced by first emergence count and speed emergence index, was promoted by immersion of the seeds in $\mathrm{H}_{2} \mathrm{SO}_{4}$ for 45 and 60 minutes (Table 2).

These emergence results concur with the germination results (Table 1 and Figure 1). The immersion of the seeds in $\mathrm{H}_{2} \mathrm{SO}_{4}$ for 45 and 60 minutes probably caused integument rupture, but without damaging the embryo, thereby promoting imbibition when they were sowed in a humid substrate. This would have promoted the germination and consequently, the emergence of the seedlings. In the laboratory or nursery, it is desirable to reduce germination and emergence times, because the faster these processes occur, the shorter the time the seeds will be vulnerable to adverse environment factors such as attacks from microorganisms (Barros, Martins, Silva, \& Martins, 2017).

In comparison to the control, immersion in hot water, cold water, and $\mathrm{H}_{2} \mathrm{SO}_{4}$ for 15 minutes did not cause significant changes in the percentages of seed emergence and first count, and emergence speed 
index. These results therefore corroborate those obtained in Tables 1 and 2 regarding the inefficiency of these treatment methods in overcoming seed dormancy of $B$. scandens and promoting seedling growth.

\section{Conclusion}

B. scandens seeds should be immersed in $\mathrm{H}_{2} \mathrm{SO}_{4}$ for 45 and 60 minutes before sowing to overcome dormancy, in order to promote and standardize seed germination and enhance initial growth of the seedlings.

\section{Acknowledgment}

This study was financed in part by the Coordenação de Aperfeiçoamento de Pessoal de Nível Superior - Brasil (CAPES) - Finance Code 001 and by the Conselho Nacional de Desenvolvimento Científico e Tecnológico.

\section{References}

Ahmed, A. S., Elgorashi, E. E., Moodley, N., McGaw, L. J., Naidoo, V., \& Eloff, J. N. (2012). The antimicrobial, antioxidative, anti-inflammatory activity and cytotoxicity of different fractions of four South African Bauhinia species used traditionally to treat diarrhea. Journal of Ethnopharmacology, 143(3), 826-839. doi: 10.1016/j.jep.2012.08.004

Albuquerque, U. P., Simara, A. B. P., \& Silva, A. V. (2000). Pharmaco botanical study of species in the treatment of diabetes. Acta Farmaceutica Bonarens, 19(1), 7-12.

Alves, A. U., Dornelas, C. S. M., Bruno, R. L. A., Andrade, L. A., \& Alves, E. U. (2004). Superação da dormência em sementes de Bauhinia divaricata L. Acta Botânica Brasilica, 18(4), 871-879 doi: 10.1590/S0102-33062004000400018

Alves, E. U., Andrade, L. A. de, Barros, H. H. de A., Gonçalves, E. P., Alves, A. U., Gonçalves, G. S.,... Cardoso, E. de A. (2008). Substratos para testes de emergência de plântulas e vigor de sementes de Erythrina velutina Willd., Fabaceae. Semina: Ciências Agrárias, 29(1), 69-82 doi: 10.5433/1679-0359.2008v29n1p69
Alves, M. C. S., Medeiros, S., $F^{o}$., Andrade, M., Neto, \& Teófilo, E. M. (2000). Superação da dormência em sementes de Bauhinia monandra Britt. E Bauhinia ungulata L. - CAESALPINOIDEAE. Revista Brasileira de Sementes, 22(2), 139-144. doi: 10.17801/0101-3122/rbs.v22n2p139-144

Ataíde, G. M., Bicalho, E. M., Dias, D. C. F. S., Castro, R. V. O., \& Alvarenga, E. M. (2013). Superação da dormência das sementes de Delonix regia (Bojer ex Hook.) Raf. Revista Árvore, 37(6), 1145-1152. doi:10.1590/S0100-67622013000600016

Bacher, L. B. (2018). A Bauhinia Trepadeira Bauhinia scandens. Recuperado de http://www. fazendacitra.com.br/site/index.php?option $=\mathrm{com}_{-}$ content\&view $=$ article\&id $=85:$ a - bauhiniatrepadeira-bauhinia-scandens\&catid=16:plantasraras\&Itemid $=27$.

Barros, R. T. de, Martins, C. C., Silva, G. Z., \& Martins, D. (2017). Origin and temperature on the germination of beggartick seeds. Revista Brasileira de Engenharia Agrícola e Ambiental, 21(7), 448-453. doi: 10.1590/1807-1929/agriambi.v21n7p448-453

Ministério da Agricultura, Pecuária e Abastecimento. (2009). Regras para análise de sementes. Secretaria de Defesa Agropecuária. Brasília: MAPA/ACS.

Ministério da Agricultura, Pecuária e Abastecimento. 2013. Instruções para análise de sementes de espécies florestais. Brasília: MAPA/ACS.

Cruz, E. D., Carvalho, J. E. U. de, Oliveira, R. P. de. (1997). Variabilidade na germinação e dormência em sementes de Centrosema pubescens Benth. Pasturas Tropicales, 19(1), 37-41.

Gomes, D. R., Lopes, J. C., Silva, A. G. da, \& Matheus, M. T. (2012). Frequência relativa de germinação em sementes de rabo de pitu (Chamaecrista desvauxii (Colladon) Killip) em casa de vegetação. Enciclopédia Biosfera, 8(14), 606.

Hazra, A. G., \& Chatterjee, P. (2008). A nontoxic antitumour compound from the leaves of Bauhinia scandens characterized as 1- O-alkyl glycerol by gas-liquid chromatography and evaluation of its antitumour property by Brine Shrimp bioassay. Industrial Crops and Products, 27(1), 39-43 doi: 10.1016/j.indcrop.2007.07.005

Jeromini, T. S., Scalon, S. P. de. Q., Pereira, S. T. S., Fachinelli, R., \& Scalon, H., Fo. (2015). Armazenamento de sementes e sombreamento na emergência e crescimento inicial das mudas de Magonia pubescens ST. HIL. Revista Árvore, 39(4), 683-690. doi:10.1590/0100-67622015000400010 
Labouriau, L. G., \& Valadares, M. B. (1976). On the germination of seeds of Calotropis procera. Anais da Academia Brasileira de Ciências, 48(1), 174-186.

Labouriau, L. G. (1983). A germinação das sementes. Washington: Secretaria Geral da Organização dos Estados Americanos.

Lopes, J. C., Barbosa, L. G., \& Capucho, M. T. (2007). Germinação de sementes de Bauhinia ssp. Revista Floresta, 37(2), 265-273. doi: 10.5380/rf.v37i2.8658

Maguire, J. D. (1962). Speed of germination: aid in selection and evaluating for seedling emergence and vigor. Crop Science, 2(1), 176-177.

Martins, C. C., \& Nakagawa, J. (2008). Germinação de sementes de Stryphnodendron adstringens (Mart.) Coville de diferentes origens submetidas a tratamentos para superação de dormência. Revista Árvore, 32(6), 1059-1067. doi: 10.1590/S010067622008000600011

Martins, C. C., Machado, C. G., Martinelli-Seneme, A., \& Zucareli, C. (2012). Método de colheita e superação de dormência na qualidade fisiológica de sementes de Cassia ferrugínea. Semina: Ciências Agrárias, 33(2), 491-498 doi: 10.5433/1679-0359.2012v33n $2 \mathrm{p} 491$

Melo, J. G. de, Nascimento, V. T. do, Amorim, E. L. C. de, Andrade Lima, C. S., \& Albuquerque, U. P. (2004). Avaliação da qualidade de amostras comerciais de boldo (Peumus boldus Molina), pata-de-vaca (Bauhinia spp.) e ginco (Ginkgo biloba L.). Revista Brasileira de Farmacognosia, 14(2), 111-120. doi: 10.1590/S0102-695X2004000200004

Nakagawa, J. (1999). Testes de vigor baseados no desempenho das plântulas. In Krzyzanowski, F. C., Vieira, R. D., Franca Neto, J. de B., Vigor de sementes: conceitos e testes. (pp. 2-1 - 2-24). Londrina: Abrates.
Oliveira, A. K. M., Ribeiro, J. W., Pereira, K. C. L., Rondon, E. V., Becker, T. J. A., \& Barbosa, L. A. (2012b). Superação de dormência em sementes de Parkia gigantocarpa (Fabaceae Mimosidae). Ciência Florestal, 22(3), 533-540. doi: $10.5902 / 198050986620$

Oliveira, T. M., Amaral, G. C., Farias, S. G. G., Alves, A. R., Maia, E. L., \& Santos, L. M. (2012a). Superação de dormência de sementes de mororó (Bauhinia forficata Linn.). Scientia Plena, 8(4), 49-58.

Pereira, A. C. S., Ribeiro, G. E., Souza, L. C. R., Rufino, L. R. A., Cabral, I. S. R., Boriollo, M. F. G.,... Fiorini, J. E. (2014). Atividade biológica do extrato hidroalcoólico de Bauhinia forficata Link sobre Herpetomonas samuelpessoai (Galvão.) Roitman. Revista Brasileira de Plantas Medicinais, 16(3), 585-592. doi: 10.1590/1983-084X/13_093

Poonsri, A. W., Pluempanupat, W., Chitchirachan, P., Bullangpoti, V., \& Koul, O. (2015). Insecticidal alkanes from Bauhinia scandens var. horsfieldii against Plutella xylostella L. (Lepidoptera: Plutellidae). Industrial Crops and Products, 65(1), 170-174 doi: 10.1016/j.indcrop.2014.11.040

Ranal, M. A., Santana, D. G. D., Ferreira, W. R., \& Mendes-Rodrigues, C. (2009). Calculating germination measurements and organizing spreadsheets. Brazilian Journal of Botany, 32(4), 849-855 doi: 10.1590/S0100-84042009000400022

Rolston, M. P. (1978). Water impermeable seed dormancy. Botanical Review, 44(2), 365-396.

Santana, D. G., \& Ranal, M. A. (2004). Análise da germinação: um enfoque estatístico. Brasília: Editora Universidade de Brasília.

Santos, F. J. B., Lima, S. G., Cerqueira, G. S., Citó, A. M. G. L., Cavalcante, A. A. C. M., Marques, T. H. C., \& Freitas, R. M. (2012) Chemical composition and anxiolytic-like effects of the Bauhinia platypetala. Brazilian Journal of Pharmacognosy, 22(3), 507516 doi: 10.1590/S0102-695X2012005000018 
